\title{
FOOD INDUSTRY DEVELOPMENT IN THE CONTEXT OF THE FOOD SECURITY OF REGIONS OF UKRAINE
}

\author{
Mykola Mykolaichuk' \\ Ukrainian Catholic University, Ukraine \\ Odesa Regional Institute for Public Administration of National Academy for Public Administration \\ under the President of Ukraine, Ukraine
}

Nataliya Mykolaichuk ${ }^{2}$

Kherson National Technical University, Ukraine

\begin{abstract}
The purpose of the study is to substantiate the food security needs in the regions of Ukraine, as well as the definition of tasks in filling the market with own production products. The obtained results will determine the directions of structural changes in agricultural complexes of the regions and the necessary measures by the public regulatory bodies. Methodology. The research is based on a comparison of results of normative and search forecasts. In developing normative forecasts, the projected population and needs in different types of products according to the norms of rational consumption are taken into account. Search forecasts provide for the definition of a future state of satisfaction with the preservation of existing development trends. The gap between the necessary and projected results determines the task of accelerating growth. In terms of national security, food production should be provided with its own raw material base. Therefore, an analysis of the conditions for the development of livestock and crop production is necessary, which enables to substantiate the directions of systemic changes in agricultural complexes of the regions. In order to ensure positive changes in the structure of agricultural production, strengthening the effectiveness of public regulation on the basis of financial and economic leverage is needed. Results. Regions of Ukraine by territory and population exceed certain countries of the European Union. Significant differences in socio-economic conditions of the regions contribute to the growth of tension in society and migration. The events of recent years indicate the possibility of external interference in the functioning of the regions of Ukraine and the danger of the collapse of cooperative ties. Therefore, it is important to ensure the satisfaction of the immediate needs of the population of each region at the expense of its own production. Among the necessities, food occupies a special place. Complete nutrition is one of the prerequisites for increasing the life expectancy of the population. The development of the production of these goods positively affects the economy, because it provides employment, rapid cash flow, and budget filling. However, food consumption is limited by physiological needs. Therefore, the potential capacity of the food market depends on the demographic structure, population size, and rational consumption standards. According to the results of the study, excessive consumption of bread and potatoes by Ukrainian people and too little consumed meat and dairy products, fruits are detected. During the years of Ukraine's independence, the share of livestock farming in agricultural complexes of regions has significantly decreased. In plant growing, there are also structural changes in the direction of reducing the forage base and increasing crop areas under technical crops that deplete the land. These changes threaten the irreversible loss of soil fertility. Therefore, governmental stimulation is required not only for the revival of livestock but also for the rational use of sown areas. Practical implications. The results of a comparative assessment of the potential capacity of regional food markets with the current state of satisfaction of the population's needs will reveal the necessary directions for the development of the food industry and agriculture of the regions. Value/originality. A systematic approach to the formation of plans for the development of the food industry that meets the requirements of food security and the corresponding changes in the ratio of livestock and crop

\footnotetext{
Corresponding author:

${ }^{1}$ Department of Public Administration, Ukrainian Catholic University.

Department of Economic and Finance Policy, Odesa Regional Institute for Public Administration of National Academy for Public

Administration under the President of Ukraine.

E-mail: myk3chuk@gmail.com

${ }^{2}$ Centre for Retraining and Skills Upgrading, Kherson National Technical University.

E-mail:nsmyk45@gmail.com
} 
production, the structure of crop areas is proposed. This approach has not only a scientific novelty but also contributes to increasing the positive impact of the food industry on the sustainable development of both individual regions and the country as a whole.

Key words: food security, regions, food industry, forecasting, factors of influence.

JEL Classification: E27, F52, Q18, R11, R58

\section{Introduction}

Issues of food security have a global significance. However, there are different approaches to the interpretation of food security objectives and ways to achieve it. The Report "State of Food Security and Nutrition in the World 2017" defines food security as "... situation that exists when all people, at all times, have physical, social, and economic access to sufficient, safe and nutritious food that meets their dietary needs and food preferences for an active and healthy life." On the basis of this definition, four dimensions of food security are distinguished: food availability, economic and physical availability of food, utilization of used food and time stability. Thus, the causes of food insecurity or failure may be: the absence or insufficiency of food, insufficient purchasing power, inappropriate distribution, or inadequate use of food (FAO, IFAD, UNICEF, WFP and WHO, 2017). According to the report, Europe, as well as North America, has a lower rate of $2.5 \%$ of the population suffering from malnutrition. This is the best indicator in the world, but a part of the second report focuses on the interconnection of armed conflicts with food security. Among the causes of armed conflict, we will distinguish external (Russia's aggression against Georgia in 2008 and Ukraine from 2014 to the present time) and internal (the struggle for the independence of the republics of the Caucasian region in Russia). However, in our opinion, significant differences in the socio-economic development of the regions of the country can also be the cause of internal conflicts.

The Global Food Security Index was developed by the Analytical Department of Economic Intelligence with the support of DuPont Company. Since 2012, this indicator has taken into account three main components: affordability (40.0\%), availability (44.0\%), quality and safety $(16.0 \%)$. Since 2017 , the fourth category has been added to reflect the impact of climate and natural resources. The overall score is now calculated from the simple average weighted score of the main three categories, and the category "Natural Resources and Sustainability" is a correction factor. Consequently, the fourth component demonstrates changes in the overall assessment, taking into account the risks associated with climate and natural resources.

Global Food Security Index is calculated for 113 countries. Of these, 26 countries belong to Europe. The European Union is represented by 20 countries with a population of over 5 million people. In the overall ranking, Ukraine with the index 54.1 from 100 takes the $63 \mathrm{rd}$ position. The nearest neighbours in the ranking from the countries of Europe and the EU, respectively, is Serbia with the indicator 60.6 (50th position) and Bulgaria with the indicator 62.9 (47th position). A similar situation remains with all the components, except for quality and safety, where Ukraine is one position ahead of Serbia and three of Bulgaria (The Economist Intelligence Unit Limited, 2017).

This is not surprising since in recent years attacks on the territorial integrity of Ukraine and related military actions have been struck by a devastating blow to its economy. In the difficult conditions of the struggle for the independence and integrity of the state, Ukraine needs not only to stop the destruction of the economy but also to create conditions for the economic growth. Achievements in the development of the national economy are significantly dependent on the results of the development of its components that can be allocated on a territorial or sectoral basis.

On a territorial basis, Ukraine is divided into regions that are identified with administrative regions - "oblasts". In today's conditions, the level of socio-economic development of regions is significantly different. Thus, in 2015, the gross regional product (GRP) per capita in the Chernivtsi oblast is almost in 2.3 times lower than the average in Ukraine and in 3.2 times less than in the Poltava and Dnipropetrovsk oblasts. Below average and indicators of the GRP of the southern regions: Odesa oblast - at $10.0 \%$, Mykolaiv oblast - at $11.0 \%$, Kherson oblast - at $35.0 \%$. From the leading regions, they fall at $36.7 \%$, at $37.0 \%$, and at $54.1 \%$, respectively. Significant differences also occur in the average wage. The highest wages for 2015-2016 were in Donetsk oblast (at 18.7\% and at $15.6 \%$ higher than the average in Ukraine), while in Chernivtsi oblast it was in 1.4 times less than the average in Ukraine and almost at in 1.6 times lower than the Donetsk region. In the Mykolaiv oblast, the level of remuneration is at $5.7 \%$ lower than the average for Ukraine, Odesa oblast - at 7.2\%, Kherson oblast - at $22.0 \%$. The gap between the level of remuneration in Kherson and Donetsk oblasts exceeds 30.0\% (Verner, 2017 (Part II), p. 18 and Verner, 2017 (Part I), p. 102).

From the point of view of economic security of the country, it is necessary to reduce the differences between the level of socio-economic development of the regions, to provide them with a certain self-sufficiency in meeting the primary needs of the population, providing social services, creating conditions for comfortable living 
and personal development, directing the community's efforts to improve the competitiveness of the region, and countries. Among the components of general economic security, which have a strong influence, but significantly behind the desired level, is food security (Kharazishvili, Dron, 2014).

During the years of the first decade of independence, Ukraine has significantly reduced the volume as industrial and agricultural production, which results in the new millennium meat products consumption reached only $42.5 \%$ of the norm, milk - 56.7\%, vegetables - $58.4 \%$, fruits and berries $-27.4 \%$. The volumes of agricultural products, which are raw material suppliers for food industry enterprises, accounted for only $53.4 \%$ of the volume of 1990 . At the same time, there was a significant divergence in the situation in the regions. Thus, in the Zakarpattia oblast, agricultural production reached $81.8 \%$ of the 1990 level, in Kherson oblast it was $44.2 \%$, while Mykolaiv's index was only 41.0\% (Pepa, 2001, p. 175 and Osaulenko, 2008, p. $147,148)$. For the period up to 2015 , the volume of agricultural production has increased substantially, but it was still only $84.6 \%$ of the 1990 level in the country (calculated from Osaulenko, 2008, p. 147 and Verner, 2017 (Part II), p. 202).

In order to meet the needs of the population and form the export potential, it is necessary to determine sufficient quantities of food for domestic consumption according to rational standards. Therefore, the purpose of the article is to substantiate the level of food production in the regions of Ukraine, which is necessary in terms of food security, and also to identify problems in filling the market with products of its own production. Implementation of the objectives requires a systematic approach to determining the desired structural changes in the agricultural sector in the region and the necessary measures of state regulation based on a comparison of estimated potential market size of food from the expected results of the food industry based on existing trends, identify factors influencing the amount and direction of action.

\section{Forecasting capacity of regional food markets}

In determining the potential capacity of markets, it is necessary to take into account not only the existing and future needs of the population but also the assessment of the positive and negative effects of certain changes in various spheres of activity of the country and the region.

Potential capacity characterizes the highest level of consumption under favourable conditions and is determined on the basis of forecasting. It is a prediction that provides a proactive reflection of reality.

Future needs should be determined on the basis of normative forecasts, which reflect the idealized results. Adding them to search forecasts, which are built from the past to the future, and foresee a future state while preserving the existing development trends, helps to choose the variant of development that contributes to the achievement of the goal.

Forecasting the capacity of markets for products for different purposes has its own peculiarities. So, the capacity of a food market depends on the population size and physiological needs in different products. To substantiate the need for food products, first of all, it is necessary to determine the expected population in the region.

Existing trends in population growth in the southern regions are described by polynomial trends and are presented in Table 1 .

Table 1

Trends and forecast of the population *

\begin{tabular}{|c|c|c|c|}
\hline $\begin{array}{c}\text { Region } \\
\text { (oblast) }\end{array}$ & Trend & $\mathrm{R}^{2}$ & $\begin{array}{c}\text { Estimated number } \\
\text { in 2020, thousand }\end{array}$ \\
\hline Odesa & $\begin{array}{c}\mathrm{Y}=2482,5+ \\
+0,7518 \mathrm{t} 2-16,813 \mathrm{t}\end{array}$ & 0,9135 & 2446,96 \\
\hline Mykolaiv & $\begin{array}{c}\mathrm{Y}=1291,4+ \\
+0,3761 \mathrm{t} 2-14,083 \mathrm{t}\end{array}$ & 0,9983 & 1160,18 \\
\hline Kherson & $\begin{array}{c}\mathrm{Y}=1204,0+ \\
+0,4265 \mathrm{t} 2-15,338 \mathrm{t}\end{array}$ & 0,9992 & 1067,80 \\
\hline
\end{tabular}

${ }^{*} Y$ - population, thousand people;

$t$ - serial number of the year (base year is 2001);

$R$ - coefficient of determination

Table 2

Estimated need for food for the Southern regions of Ukraine

\begin{tabular}{|c|l|c|c|c|c|}
\hline \multirow{2}{*}{ № } & \multirow{2}{*}{ Commodity group } & \multirow{2}{*}{$\begin{array}{c}\text { Rational consumption ratios } \\
(\mathrm{kg} / \text { year per capita) }\end{array}$} & \multicolumn{3}{|c|}{ Need of the regions, thousand tons (pieces) for 2020 } \\
\cline { 4 - 6 } & & 83 & 96,3 & Odesa oblast & Kherson oblast \\
\hline 1 & Meat and meat products & 380 & 440,9 & 929,8 & 88,6 \\
\hline 2 & Milk and dairy products & 290 & 336,4 & 709,6 & 405,8 \\
\hline 3 & Eggs (pieces) & 20 & 23,2 & 48,9 & 309,6 \\
\hline 4 & Fish and fish products & 38 & 44,1 & 93,0 & 21,4 \\
\hline 5 & Sugar & 13 & 15,1 & 31,8 & 13,6 \\
\hline 6 & Oil and other vegetable fats & 124 & 143,9 & 303,4 & 132,4 \\
\hline 7 & Potato & 161 & 186,8 & 394,0 & 171,9 \\
\hline 8 & Vegetables and melons & 90 & 104,4 & 220,2 & 96,1 \\
\hline 9 & Fruits, berries, grapes, nuts & 101 & 117,2 & 247,1 & 107,8 \\
\hline 10 & Bread and bread products & & &
\end{tabular}


The value of the determination coefficient indicates that more than $90 \%$ of the population changes correspond to the indicated patterns. Therefore, it is possible to determine the expected population based on this model in 2020.

The expected number determines the need for food (Table 2).

At the beginning of the new millennium, the Open Joint-Stock Company "Ukrainian Research Institute of Nutrition" developed the norms (recommended) and the minimum consumer basket under the conditions of the socio-economic crisis. It should be noted that they are almost $20 \%$ lower than actual consumption in developed countries (Yegorov, Mardar, 2011).

\section{Trends in satisfying food needs.}

The potential capacity of the domestic market reflects the desired results, the ability to achieve which depends on many factors and requires active action, financial resources, and time. To determine the directions of action, resource requirements, it is necessary to compare the desired results with expectations based on the passive forecast.

Traditionally, too much bread, potatoes, and sugar are consumed in Ukraine. In 1990, the production was sufficient to meet the minimum requirements for the consumption of meat, milk, eggs, fish, but vegetables and fruits consumed less than normal. The consumption of bread and bakery products exceeded the recommended norms at $39.6 \%$, sugar - at $31.6 \%$, potatoes - at 5.6\% (calculated from Osaulenko, 2008, p. 434). In subsequent years, consumption of products of all species (except for potatoes) decreased significantly; positive changes began to be observed only in 2005 .

Excessively high consumption of Ukrainian oil, potatoes, and bakery products is due to the relatively low solvency of the population. The effects of unbalanced nutrition are increasing mortality and reducing the life expectancy of the population. According to WHO data, in countries where the population consumes a lot of vegetables and fruits, the mortality rate from circulatory system diseases decreases (Yegorov, Mardar, 2011). High-quality balanced nutrition significantly reduces the risk of diabetes and mortality from oncological diseases.

With the preservation of existing trends, the needs for rational consumption standards will satisfy the production of bread and bakery products, oils, sugar, vegetables and melons, potatoes, eggs and a possible approximation to rational standards for consumption of fish products. The highest level of production and consumption of food products was observed in 2013 but the situation deteriorated in further. In 2013, the average for Ukraine consumed $14.6 \mathrm{~kg}$ of fish products per capita, the needs of residents of Kyiv region were satisfied by the rational norm. The consumption of this product in the Odesa oblast amounted to $88.5 \%$ of the rationale norm, Mykolaiv oblast $-85.5 \%$, Kherson oblast $-78.5 \%$ (calculated from State Statistics Service of Ukraine, 2016).

The situation with the provision of benefit products for the public such as fruits, berries, nuts, grapes is much worse. In general in Ukraine in 2013, the population consumed only $62.5 \%$ of the rational norms: Odesa oblast $-65.0 \%$, Mykolaiv oblast - 61.0\%, Kherson oblast $-60.6 \%$ (calculated from State Statistics Service of Ukraine, 2016).

In the development of passive forecasts, equations of trends, which allow determining the predicted level of indicators while preserving existing trends, are used the most often.

Sustained positive trends are observed in changing the consumption of fruits, berries and grapes:

$$
\mathrm{Y}=23,438+2,2286 \mathrm{t} \text {, }
$$

where $t$ - the serial number of the time period

The value of $R^{2}=0,9638$ indicates the high reliability of this trend.

The predicted value of the level of consumption of fruit and berries in Ukraine by one person in 2020 will be $70 \mathrm{~kg}$, which is $22.0 \%$ less than the rationale norm.

The greatest problems arise in providing the population of Ukraine with meat and dairy products. So, before Russia's aggression in 2013, consumption of meat and meat products in Ukraine as a whole was $67.5 \%$ of the norm, in the southern regions it was even lower: in the Kherson oblast $-62.1 \%$ of the norm, Mykolaiv oblast $61.9 \%$, Odesa oblast $-58.0 \%$. In 2015, the figure in Ukraine decreased to $55.2 \%$, Mykolaiv oblast - 53.2\%, Odesa - 57.8\%, Kherson - 61.3\% (calculated from State Statistics Service of Ukraine, 2016). In 2013, the consumption of dairy products in Ukraine accounted for $58.1 \%$ of the rationale norm, in Kherson region it was $51.7 \%$, Odesa $-50.5 \%$, and in the Mykolaiv oblast consumption was more than the average in Ukraine $59.8 \%$ of the norm. In 2015, the average dropped to $55.2 \%$. Even lower were indicators in the southern regions: $54.4 \%$ - in the Mykolaiv oblast; $51.5 \%$ - in Kherson oblast; $51.2 \%$ - in the Odesa oblast (calculated from State Statistics Service of Ukraine, 2016).

The equation of the trend of consumption of meat and meat products by one person per year is as follows:

$$
\mathrm{Y}=28,952+1,9393 \mathrm{t} \text {, }
$$

where $\mathrm{t}$ - the serial number of the time period.

The value of $R^{2}=0,9489$ indicates the high reliability of this trend.

The predicted value of the level of consumption of meat and meat products in Ukraine by one person in 2020 will be $67 \mathrm{~kg}$, which is $20.0 \%$ less than the rationale norm.

In the consumption of milk and dairy products in the period from 2000 to 2014, there were temporary surges and a drop in indicators that were not regular. At the end 
of the period, the level reached $223 \mathrm{~kg}$, which was close to the $225 \mathrm{~kg}$ stable enough in 2002-2007. But this is only $57.0 \%$ of the rational norm.

\section{Factors affecting the production of food}

It should be noted that the problems of ensuring the population of meat and dairy products have a chain character. An increase in food production is possible only with the corresponding increase in livestock and sown areas planted for the cultivation of forage crops and the increase in their yields. However, there are opposite trends. In the period from 1990 to 2015, the share of livestock production in agricultural products decreased from $54.4 \%$ to $29.7 \%$, the number of cattle from 24623 thousand heads to 3750 thousand heads (that is in 6.6 times and constitutes only $33.5 \%$ of its number in 1950), the livestock of pigs decreased in 2.7 times and reached only $91.0 \%$ of the presence of these animals in 1950 (calculated from Zhuk, 2016). Thus, the restoration of livestock will contribute to improving not only the satisfaction of the needs of the population in meat products, dairy products, but also the restoration of the cultivation of fodder crops, which will positively affect the state of land resources. Also, the amount of organic fertilizers will increase.

The area occupied by forage crops in 1990 comprised $37.0 \%$ of the total cultivated area, the technical culture had to only $11.6 \%$. In 2015 , the share of forage crops decreased to $7.4 \%$, and the employment of technical crops increased to $31.0 \%$. The southern regions have a similar structure of crop area. In the Mykolaiv oblast, $32.9 \%$ of crop area is under technical crops, 3.5\% are under forage. In the Odesa oblast, respectively: $26.6 \%$ and $4.0 \%$. In Kherson oblast: $31.3 \%$ and $5.5 \%$ (calculated from Zhuk, 2016).

The reason for these changes is the commercial attractiveness of technical crops and, as a consequence, a catastrophic decline in the fertility of the land. At the request of crop rotation, sunflower may be returned to one and the same field only after 8-10 years, so the safe part of the sunflower in the crops can't exceed $10.0 \%$ (Popova, 2009). In Kherson oblast, the share of sown area sown with sunflower in the year of 1997 was $7.3 \%$, and in 2016 it was $28.0 \%$ (Voznyuk, 2017).

It adversely affects the health of the population and insufficient supply of fruits and berries. In 2014, the population consumed only $58.0 \%$ of the rationale norm for this useful product, and self-sufficiency was only $82.0 \%$. This indicates the need to increase own production volumes and reduce imports. In order to increase own production of this product, new plantations, fruit-bearing age, which occur only in a few years, are needed. But in Ukraine, the planting of fruit trees and vineyards is decreasing dramatically. In 1995, the area of fruit and berry plantations was 794 thousand hectares, in 2010 it decreased to 255 thousand hectares, and in 2015 there were only 235 thousand hectares. A similar situation with the area of vineyards, which reached 155 thousand hectares in 1995, and in 2015 there were only 45 thousand hectares (Zhuk, 2016).

It should be noted that according to the balance of food resources, the needs for meat and dairy products are covered by their own production, the level of selfsufficiency of meat products is $106.2 \%$, milk products $105.0 \%$ (State Statistics Service of Ukraine, 2016).

This indicates the need to increase the purchasing power of the population. Without solving this problem, there will be no sense in increasing production volumes. Taking into account the increase in the cost of communal services and the need to reduce the share of food expenditure, the incomes of the population should increase in 2.5-3 times.

\section{Public regulation of the food industry development of the regions}

In order to ensure positive changes in the development of the food industry of the regions, state regulation of agricultural development by economic methods is necessary. First of all, it is necessary to encourage an increase in livestock production. After all, it not only allows improving the structure of consumption of food but also helps to restore soil fertility. To do this, it is necessary to have an average of 1 ha of arable land a certain number of animals: 2-3 cows, or 25 pigs, or 2500 chickens (Vlasenko, 2014).

There must be financial benefits in growing fodder crops, maintaining soil fertility. It is necessary to ensure balanced production of various crops taking into account their impact on soil fertility and recommendations of experts on rational crop rotation. Observance of scientific recommendations for crop rotation is possible only with the provision of land plots for rent for a period of at least 20 years. In this case, it is necessary to reflect in the agreement the state of the land resources and the obligation to maintain it (or improvement) until the end of the lease term.

In the regions, it is advisable to create trust funds for ecologically safe land use. This corresponds to the global experience of creating various non-governmental organizations, as well as legislative regulation at the local level of the relationship between business entities. Thus, the law of Japan provided funding for environmental expenditures by private businesses and Canadian provinces right granted by law to regulate relations in the field of environmental protection (Dorohuntsov, Horbach, Khvesyk, Pastushenko, 2007). In the conditions of decentralization of public power, it is desirable in Ukraine to give local authorities the right to regulate relations on environmental protection. In particular, experts suggest the use of the following economic measures: the release of landowners and land users from land payment, which are being implemented measures to improve their condition; 
providing tax and credit privileges to those who, at their own expense, embody measures to protect and enhance soil fertility; introduction of land insurance against the reduction of their qualitative state in case of force majeure; the introduction of sanctions for inefficient land use (Vlasenko, 2014). From the point of view of the authors, the sanction payments must compensate for the costs of fertilizing the soil, which is reflected in the resumption of humus quantities. In order to maintain the soil fertility, it is necessary to maintain a balance of humus, that is, its income in the amount not less than that lost due to erosion processes and its removal by agricultural crops. Depending on the structure of the crop area, an annual reduction of humus reaches 0.6-1.4 tons per 1 hectare. To restore it, it is necessary to add organic fertilizers in the amount of 12-28 tons per hectare. In fact, over the past 15 years, 2-3 tons of organic fertilizers have been introduced (Gorlachuk, Struchenko, 2007). Comparison in the process of monitoring the actual state of land with the indicators reflected in the agreements allows you to determine the compensation costs for the restoration of soil fertility.

\section{Conclusions}

The development of the food industry is of particular importance in terms of both food and economic security of the country and its regions. Balanced nutrition creates the preconditions for a healthy lifestyle by preventing cardiovascular, cancer, reducing mortality and increasing the life expectancy of the population. Therefore, it is necessary to predict the population and the necessary quantities of food production according to rational standards, the corresponding demand for livestock and crop products.

The analysis of existing tendencies in the development of the food industry and factors influencing it makes it possible to determine the necessary growth rates of different types of products for the formation of an optimal assortment of food products, to substantiate changes in the structure of agricultural complexes of regions.

To achieve positive changes, it is necessary to improve the financial and economic methods of state regulation of agricultural development, in particular, to stimulate the development of livestock and rational nature management. It is also important to increase the solvency of the population.

Prospects for further research are seen in adapting the methodology for determining the index of food security as the macro-regions of Ukraine (South, West, North, Centre, etc.), as well as EU macro-regions, for example, the Baltic Countries.

\section{References:}

Dorohuntsov, S. I., Horbach, L. M., Khvesyk, M. A., Pastushenko, P. P. (2007). Ekoseredovyshche ta yevrointehratsiini protsesy: Monohrafiia [Eco-environment and European integration processes: Monograph]. (Vol. 6). Kyiv: Kondor. (in Ukrainian)

FAO, IFAD, UNICEF, WFP and WHO (2017). The State of Food Security and Nutrition in the World 2017. Building resilience for peace and food security. Web page. Retrieved from: http://www.fao.org/fileadmin/user upload newsroom/docs/20170328_Full\%20Report_Global\%20Report\%20on\%20Food\%20Crises_v1.pdf (accessed 21 December 2017)

Gorlachuk, V., Struchenko, A. (2007). Problemy zberezhennia rodiuchosti hruntiv fermerskykh hospodarstv [Problems of preservation of fertility of soils of farms]. Economy of Ukraine, (3), 74-79.

Kharazishvili, Yu. M., Dron, E. V. (2014). Prohnozuvannia indykatoriv, porohovykh znachen ta rivnia ekonomichnoi bezpeky Ukrainy u serednostrokovii perspektyvi. Analitychna dopovid [Forecasting of indicators, threshold values and level of economic security of Ukraine in the medium-term perspective. Analytical Report]. Kyiv: National Institute for Strategic Studies. (in Ukrainian)

Osaulenko, A. G. (Ed.). (2008). Statystychnyi shchorichnyk Ukrainy za 2007 rik [Statistical Yearbook of Ukraine for 2007]. Kyiv: Konsultant. Retrieved from: http://www.ukrstat.gov.ua/druk/publicat/kat_u/publ1_u.htm

Pepa, T. V. (2001). Kharchova promyslovist yak osnova formuvannia eksportnoho prodovolchoho potentsialu [Food industry as the basis for the formation of export food potential]. Strategy of economic development of Ukraine, 6, 173-179.

Popova, O. L. (2009). Stalyi rozvytok ahrosfery Ukrainy: polityka i mekhanizmy [Sustainable development of the agrosphere of Ukraine: policies and mechanisms]. Kyiv: Institute of Economics and Forecasting of the National Academy of Sciences of Ukraine. (in Ukrainian)

State Statistics Service of Ukraine (2016). Balansy ta spozhyvannia osnovnykh produktiv kharchuvannia naselenniam Ukrainy [Balance and consumption of basic food products by the population of Ukraine], Kyiv: State Statistics Service of Ukraine. Retrieved from: http://www.ukrstat.gov.ua/druk/publicat/kat_u/publ2_u.htm (accessed 22 December 2017)

The Economist Intelligence Unit Limited (2017) Global Food Security Index Web page. Retrieved from: http:// foodsecurityindex.eiu.com/ (accessed 20 December 2017)

Verner, I. E. (Ed.). (2017). Statystychnyi zbirnyk "Rehiony Ukrainy" 2017, chastyna II [Statistical bulletin "Regions of Ukraine" 2017, Part II]. Kyiv: State Statistics Service of Ukraine. Retrieved from: http://www.ukrstat.gov.ua/ druk/ publicat/kat_u/publ2_u.htm (accessed 20 December 2017) 
Verner, I. E. (Ed.). (2017). Statystychnyi zbirnyk "Rehiony Ukrainy" 2017, chastyna I [Statistical bulletin "Regions of Ukraine" 2017, Part I]. Kyiv: State Statistics Service of Ukraine. Retrieved from: http://www.ukrstat.gov.ua/druk/ publicat/kat_u/publ2_u.htm (accessed 20 December 2017)

Vlasenko, I. V. (2014). Pryntsypy funktsionuvannia ekolohobezpechnoho zemlekorystuvannia v silskomu hospodarstvi [Principles of the ecological-safety land use functioning in agriculture]. Balanced nature management, (1), 136-141.

Voznyuk, V. A. (Ed.). (2017). Statystychnyi shchorichnyk Khersonskoi oblasti za 2016 rik [Statistical Yearbook of Kherson Oblast for 2016]. Kherson: Chief Department of Statistics in the Kherson region. (in Ukrainian)

Yegorov, B., Mardar, M. (2011). Stan kharchuvannia naselennia Ukrainy [State of Ukrainian population nutrition]. Commodities and markets, 11(1), 140-147.

Zhuk, I. M. (Ed.). (2016). Statystychnyi shchorichnyk Ukrainy za 2015 rik [Statistical Yearbook of Ukraine for 2015]. Kyiv: State Statistics Service of Ukraine. Retrieved from: http://www.ukrstat.gov.ua/druk/publicat/kat_u/ publ1_u.htm (accessed 20 December 2017) 